medRxiv preprint doi: https://doi.org/10.1101/2021.07.16.21260648; this version posted July 22, 2021. The copyright holder for this preprint (which was not certified by peer review) is the author/funder, who has granted medRxiv a license to display the preprint in perpetuity.

It is made available under a CC-BY-NC 4.0 International license .

\title{
Surveillance of seasonal respiratory viruses among Chilean patients during the
}

\section{COVID-19 pandemic.}

Luis A. Alonso-Palomares ${ }^{1,3,5^{*}}$, C. Joaquín Cáceres ${ }^{6}$, Rodrigo Tapia², Paulina AguileraCortés $^{3,5}$, Santiago Valenzuela ${ }^{4}$, Fernando Valiente-Echeverría ${ }^{1,3,5}$, Ricardo Soto-Rifo ${ }^{1,3,5}$, Aldo Gaggero ${ }^{1,4}$, and Gonzalo P. Barriga ${ }^{1,2 \#}$.

1 SARS-CoV-2 Research Group, Virology Program, Institute of Biomedical Sciences, Faculty of Medicine, Universidad de Chile.

2 Laboratory of Emerging Viruses, Virology Program, Institute of Biomedical Sciences, Faculty of Medicine, Universidad de Chile

3 Laboratory of Molecular and Cellular Virology, Virology Program, Institute of Biomedical Sciences, Faculty of Medicine, Universidad de Chile

${ }^{4}$ Laboratory of Environmental Virology, Virology Program, Institute of Biomedical Sciences, Faculty of Medicine, Universidad de Chile

${ }^{5}$ HIV/AIDS Work Group, Faculty of Medicine, Universidad de Chile

${ }^{6}$ Department of Population Health, College of Veterinary Medicine, University of Georgia, Athens, Georgia, USA

\# To whom correspondence should be addressed: Dr. Gonzalo Barriga, (gonzalo.barriga@uchile.cl), Emerging Viruses Laboratory, Virology Program, Institute of Biomedical Sciences, Faculty of Medicine, Universidad de Chile, Independencia 1027, Santiago, Chile

Keywords: Surveillance, respiratory viruses, SARS-CoV-2, Influenza virus, RSV, Rhinovirus NOTE: This preprint reports new research that has not been certified by peer review and should not be used to guide clinical practice. 
medRxiv preprint doi: https://doi.org/10.1101/2021.07.16.21260648; this version posted July 22, 2021. The copyright holder for this preprint (which was not certified by peer review) is the author/funder, who has granted medRxiv a license to display the preprint in perpetuity.

\section{The Study}

SARS-CoV-2 has generated over 122 million cases worldwide. Non-pharmaceuticals

34 interventions such as confinements and lockdowns started in Chile on March $18^{\text {th }} 2020$.

In Europe, confinements and lockdowns have been accompanied by a decrease in the circulation of other respiratory viruses such as Influenza A virus(IAV), Influenza B virus(IBV) or respiratory syncytial virus(RSV) (1). Although changes in circulation patterns of respiratory viruses have been reported, limited information regarding the southern hemisphere is available where the SARS-CoV-2 pandemic merged with the winter season. We conducted viral surveillance of respiratory viruses and we evaluated their presence and establishing whether they were co-circulating with SARS-CoV-2. Few south hemisphere countries reported the same pattern than Europe where nonpharmaceutical measures began before the winter season $(2,3)$ but to the best to our knowledge, no report has been generated containing information from Chile. Here, we collected 800 nasopharyngeal-swabs samples (NSS) from 13 health care centers belonging to the north area of Santiago, Chile, between April $1^{\text {st }}$ to July $31^{\text {st }}, 2020$ (Figure 1). All samples were collected from patients with at least one COVID-19 symptoms. 400 samples were determined as positive for SARS-CoV-2. $64 \%$ percent of SARS-CoV-2 positive individuals showed age range between $23-57$ years. In addition, women had a significant incidence of positive cases, corresponding to 59\% in age range group (Figure 2).

52 Next, based on geographic location we divided the samples in 3 groups ( $A, B$ and $C)$ Figure 1. Location (A) contains the highest number of SARS-CoV-2 cases, contributing more than $50 \%$ of the positive samples analyzed in this study (Figure 1). This high positivity could be explained by the population density of location $A$, which contains at 
medRxiv preprint doi: https://doi.org/10.1101/2021.07.16.21260648; this version posted July 22, 2021. The copyright holder for this preprint (which was not certified by peer review) is the author/funder, who has granted medRxiv a license to display the preprint in perpetuity.

It is made available under a CC-BY-NC 4.0 International license.

least 4-fold more inhabitants than locations B and C (Figure 1). Nevertheless, the health

centers located in B presented positivity rates higher than $61 \%$ for SARS-CoV2 (Table 1),

except for sub-locations 9 and 10 (Figure 1), where no positive samples were obtained in the period analyzed. Location $\mathrm{C}$ is farthest location form downtown, however, still has a positivity of $54.8 \%$ indicating a homogeneous distribution of SARS-CoV-2. Taken together, our data show a high frequency of positive samples throughout the healthcare centers evaluated suggesting the population density as a risk factor for SARSCoV-2 transmission since location A and B concentrates more population than location C. These results demonstrate that the 2020 winter season in Santiago presented a high incidence of SARS-CoV-2. Then, we sought to determine in all samples whether SARS-CoV-2 was co-circulating with other respiratory viruses. We chose predominant respiratory viruses in Santiago (winter season), such as: IAV, IBV, RSV and human rhinovirus (HRV) (Table 1). Adenovirus, Parainfluenza and Metapneumovirus were not evaluated since they are considered all-year viruses (4). The results showed three samples with co-infection between IAV and SARS-CoV-2 (Table 1). This is congruent to recent studies in Ecuador and brazil showing complete decrease of $\operatorname{IAV}(5,6)$. Despite the co-circulation or coinfection between IAV and SARS-CoV-2 observed, we could not detect RSV or IBV in the SARS-CoV-2 positive samples. These results suggest an impact of the nonpharmaceutical interventions in the circulation of seasonal viruses, as previously reported in Korea and Hong Kong $(7,8)$. Next, we evaluated the presence of IAV, IBV and RSV in the samples reported as negative for SARS-CoV-2 where five positive samples for IAV and no positive samples for IBV or RSV were detected, suggesting a circulation of 
medRxiv preprint doi: https://doi.org/10.1101/2021.07.16.21260648; this version posted July 22, 2021. The copyright holder for this preprint (which was not certified by peer review) is the author/funder, who has granted medRxiv a license to display the preprint in perpetuity. It is made available under a CC-BY-NC 4.0 International license .

80 lower than the information from the northern hemisphere where a range between 2-

$8110 \%$ has been reported $(9,10)$. Taken together, these results suggest a lower co-

82 circulation of IAV with SARS-CoV-2 and co-circulation below the level of detection of this

83 study for SARS-CoV-2 together with IBV or RSV.

84 Finally, we focused on HRV, responsible for more than $50 \%$ of the cold-like illnesses, with

85 a high preponderance to coinfection with other respiratory viral pathogens(11).

86 Furthermore, HRV was the predominant virus after SARS-CoV-2 detected either

87 cocirculating with SARS-CoV-2 or circulating alone(9). The presence of HRV was

88 assessed, showing that $0.25 \%$ of the samples were co-infected SARS-CoV-2/HRV. On the

89 other hand, the HRV co-circulation was $0.8 \%$ (Table 1 ). These results establish HRV co-

90 circulation and the co-infection with SARS-CoV-2. Taken together, these results

91 demonstrate the displacement of seasonal respiratory viruses due to the presence of

92 SARS-CoV-2. Despite of this displacement, IAV and HRV are still able to keep

93 cocirculating together with SARS-CoV-2 but to a considerably lesser extent in

94 comparison with previous winter seasons.

95

96 Discussion

97 To gain insights into the potential co-circulation of the most relevant seasonally 98 circulating respiratory viruses together with SARS-CoV-2, a fact on going COVID-19 99 pandemic was that the vast majority of the SARS-CoV-2 testing during the April-July 100 period was indicated only with the presence of symptoms, we arbitrarily selected 200 101 samples per month (April to July) for a total of 800 NSS from 13 health care centers 102 located in the north zone of Santiago, Chile. 
medRxiv preprint doi: https://doi.org/10.1101/2021.07.16.21260648; this version posted July 22, 2021. The copyright holder for this preprint (which was not certified by peer review) is the author/funder, who has granted medRxiv a license to display the preprint in perpetuity. It is made available under a CC-BY-NC 4.0 International license.

103 We detected a high positivity rate by health care center between $30,4 \%-72 \%$ and we

104 observed at least twice co-infections between SARS-CoV-2/IAV or SARS-CoV-2/HRV and

105 no co-infections with IBV and RSV, which is in agreement with previously reported data

106 including the southern hemisphere $(5,12)$. Furthermore, IAV and HRV were detected

107 from negative SARS-CoV-2 samples, whereas no presence of IBV or RSV was obtained

108 even from the negative SARS-CoV-2 samples (Table 1). These results demonstrate the

109 displacement of the predominant seasonal respiratory viruses, which have an essential

110 impact during the winter season caused by the high circulation rate of SARS-CoV-2. A

111 similar phenomenon was observed after the 2009 Influenza A (H1N1) pandemic, which

112 generated a decrease of RSV and IAV H3N2 infections (13). The reduction or absence of

113 IAV, IBV or RSV observed in this study can be explained by the non-pharmaceutical

114 interventions such as confinement and lockdowns established before the beginning of

115 the winter season in March 2020. A previous report showed that SARS-CoV-2 could

116 replace within three weeks the seasonal respiratory viruses circulating (1), while that

117 HRV co-infections are one of the most commonly observed. However, the impact that

118 HRV infection co-infecting with other respiratory viruses is still unclear due to

119 inconsistencies among different studies (11). The effect of HRV in SARS-CoV-2 infection

120 and the clinical outcome is still unknown.

121 Considering that the vast majority of the SARS-CoV-2 testing during the April-July period

122 was indicated only with the presence of symptoms, potential bacterial infections or co-

123 infections cannot be ruled out in this study. The presence of bacterial infections during

124 the SARS-CoV-2 pandemic has been previously reported (14-16). A previous study

125 identified S. Pneumoniae, $K$. pneumoniae and $H$. influenza among the bacteria 
medRxiv preprint doi: https://doi.org/10.1101/2021.07.16.21260648; this version posted July 22, 2021. The copyright holder for this preprint (which was not certified by peer review) is the author/funder, who has granted medRxiv a license to display the preprint in perpetuity.

It is made available under a CC-BY-NC 4.0 International license .

126 cocirculating with SARS-CoV-2 (16). However, the detection of bacteria is beyond the

127 scope of the study

128 In conclusion, the data shows the impact of SARS-CoV-2 over the co-circulation of

129 seasonal respiratory viruses like IAV, IBV, and RSV in Chile. Our results suggest that the

130 emergence of SARS-CoV-2 in addition with different non-pharmaceutical measures

131 adopted worldwide have a detrimental impact on the circulation at least of seasonal

132 respiratory viruses. Furthermore, our data allow us to foresee the circulation of

133 respiratory viruses in the 2021 winter season in the southern hemisphere. 
medRxiv preprint doi: https://doi.org/10.1101/2021.07.16.21260648; this version posted July 22, 2021. The copyright holder for this preprint (which was not certified by peer review) is the author/funder, who has granted medRxiv a license to display the preprint in perpetuity.

\section{Conflict of interest}

136 The authors declare that there are no conflicts of interest associated with this work

\section{Ethical statement}

139 The study described here was approved by the Ethics Committee of the Faculty of

140 Medicine at Universidad de Chile (Project № 036-2020). The samples were de-identified 141 and not considered as human samples.

\section{Acknowledgments and Funding}

144 The authors are supported by Instituto Antártico Chileno (INACH) RT_35-19 (GB-P), ANID

145 Chile through Fondecyt grants № 11200228 (GB) 1181656 (AG), 1190156 (RS-R), 1461180798 (FV-E); Postdoctoral fellowship N SECTEI/138/2019 from Mexico City (LA-P). 147 Authors would like to thank the Science, Technology, Knowledge and Innovation 148 Ministry of Chile for articulating and coordinating support from the scientific 149 community. Also, we want to thank the diagnostic group of the University of Chile

Authors contributions.

152 Conceptualization: LAP, CJC and GB, Data curation: LAP, RT, PA, AG, FV-E and GB, Formal 153 analysis: LAP and GB, Funding acquisition: GB, Investigation: LAP, RT, PA, SV and GB, 154 Methodology: LAP, CJC, FAV-E, AG, RS-R and GB, Project administration: LAP, CJC, FV-E, 155 AG, RS-R and GB.

156 Supervision: LAP, FAV-E, AG, RS-R and GB, Validation: LAP, CJC, and GB, Visualization: 157 LAP, CJC, and GB, Writing-original \& draft: CJC, and GB, Writing-review \& editing: LAP, 158 CJC, FAV-E, AG, RS-R and GB, All authors approved the final version of the manuscript. 159 Gonzalo Barriga had full data access to all data in this study and takes complete 160 responsibility for the integrity of the data and the accuracy of the data analysis.

Transparency statement

163 Gonzalo Barriga affirms that this manuscript is an honest, accurate, and transparent

164 account of the study being reported; that no important aspects of the study have been omitted; and that any discrepancies from the study as planned have been explained 
medRxiv preprint doi: https://doi.org/10.1101/2021.07.16.21260648; this version posted July 22, 2021. The copyright holder for this preprint (which was not certified by peer review) is the author/funder, who has granted medRxiv a license to display the preprint in perpetuity.

It is made available under a CC-BY-NC 4.0 International license .

\section{Data availability statement}

168 The authors confirm that the data supporting the findings of this study and its 169 supplementary materials.

170 
medRxiv preprint doi: https://doi.org/10.1101/2021.07.16.21260648; this version posted July 22, 2021. The copyright holder for this preprint (which was not certified by peer review) is the author/funder, who has granted medRxiv a license to display the preprint in perpetuity.

\section{References}

172

173 1. Leuzinger K, Roloff T, Gosert R, Sogaard K, Naegele K, Rentsch K, et al. 174 Epidemiology of SARS-CoV-2 Emergence Amidst Community-Acquired Respiratory 175 Viruses. J Infect Dis. 2020 Jul 29.

176 2. Ortiz-Prado E, Simbana-Rivera K, Barreno LG, Diaz AM, Barreto A, Moyano C, et 177 al. Epidemiological, socio-demographic and clinical features of the early phase of the 178 COVID-19 epidemic in Ecuador. PLoS Negl Trop Dis. 2021 Jan;15(1):e0008958.

179 3. Goes LGB, Zerbinati RM, Tateno AF, de Souza AV, Ebach F, Corman VM, et al. 180 Typical epidemiology of respiratory virus infections in a Brazilian slum. J Med Virol. 2020 181 Aug;92(8):1316-21.

182 4. Moriyama M, Hugentobler WJ, Iwasaki A. Seasonality of Respiratory Viral 183 Infections. Annu Rev Virol. 2020 Mar 20.

184 5. Yue H, Zhang M, Xing L, Wang K, Rao X, Liu H, et al. The epidemiology and clinical 185 characteristics of co-infection of SARS-CoV-2 and influenza viruses in patients during 186 COVID-19 outbreak. J Med Virol. 2020 Jun 12.

187 6. Konala VM, Adapa S, Naramala S, Chenna A, Lamichhane S, Garlapati PR, et al. A 188 Case Series of Patients Coinfected With Influenza and COVID-19. J Investig Med High Impact Case Rep. 2020 Jan-Dec;8:2324709620934674.

$1907 . \quad$ Cowling BJ, Ali ST, Ng TWY, Tsang TK, Li JCM, Fong MW, et al. Impact assessment 191 of non-pharmaceutical interventions against coronavirus disease 2019 and influenza in 192 Hong Kong: an observational study. Lancet Public Health. 2020 May;5(5):e279-e88.

193 8. Choe YJ, Lee JK. The Impact of Social Distancing on the Transmission of Influenza 194 Virus, South Korea, 2020. Osong Public Health Res Perspect. 2020 Jun;11(3):91-2.

195 9. Nowak MD, Sordillo EM, Gitman MR, Paniz Mondolfi AE. Co-infection in SARS196 CoV-2 infected Patients: Where Are Influenza Virus and Rhinovirus/Enterovirus? J Med 197 Virol. 2020 Apr 30.

198 10. Mutnal MB, Arroliga AC, Walker K, Mohammad A, Brigmon MM, Beaver RM, et 199 al. Early trends for SARS-CoV-2 infection in central and north Texas and impact on other circulating respiratory viruses. J Med Virol. 2020 May 15.

11. Jacobs SE, Lamson DM, St George K, Walsh TJ. Human rhinoviruses. Clin Microbiol Rev. 2013 Jan;26(1):135-62.

203 12. Wu X, Cai Y, Huang X, Yu X, Zhao L, Wang F, et al. Co-infection with SARS-CoV-2 204 and Influenza A Virus in Patient with Pneumonia, China. Emerg Infect Dis. 2020 205 Jun;26(6):1324-6.

206 13. Yang L, Chan KH, Suen LK, Chan KP, Wang X, Cao P, et al. Impact of the 2009 H1N1 207 Pandemic on Age-Specific Epidemic Curves of Other Respiratory Viruses: A Comparison 208 of Pre-Pandemic, Pandemic and Post-Pandemic Periods in a Subtropical City. PLoS One. 209 2015;10(4):e0125447.

210 14. Langford BJ, So M, Raybardhan S, Leung V, Westwood D, MacFadden DR, et al. 211 Bacterial co-infection and secondary infection in patients with COVID-19: a living rapid 212 review and meta-analysis. Clin Microbiol Infect. $2020 \mathrm{Jul} 22$.

213 15. Lehmann CJ, Pho MT, Pitrak D, Ridgway JP, Pettit NN. Community Acquired Co214 infection in COVID-19: A Retrospective Observational Experience. Clin Infect Dis. 2020 215 Jul 1. 
medRxiv preprint doi: https://doi.org/10.1101/2021.07.16.21260648; this version posted July 22, 2021. The copyright holder for this preprint (which was not certified by peer review) is the author/funder, who has granted medRxiv a license to display the preprint in perpetuity.

It is made available under a CC-BY-NC 4.0 International license .

216 16. Zhu X, Ge Y, Wu T, Zhao K, Chen Y, Wu B, et al. Co-infection with respiratory

217 pathogens among COVID-2019 cases. Virus Res. 2020 Aug;285:198005.

218 
medRxiv preprint doi: https://doi.org/10.1101/2021.07.16.21260648; this version posted July 22, 2021. The copyright holder for this preprint (which was not certified by peer review) is the author/funder, who has granted medRxiv a license to display the preprint in perpetuity. It is made available under a CC-BY-NC 4.0 International license .

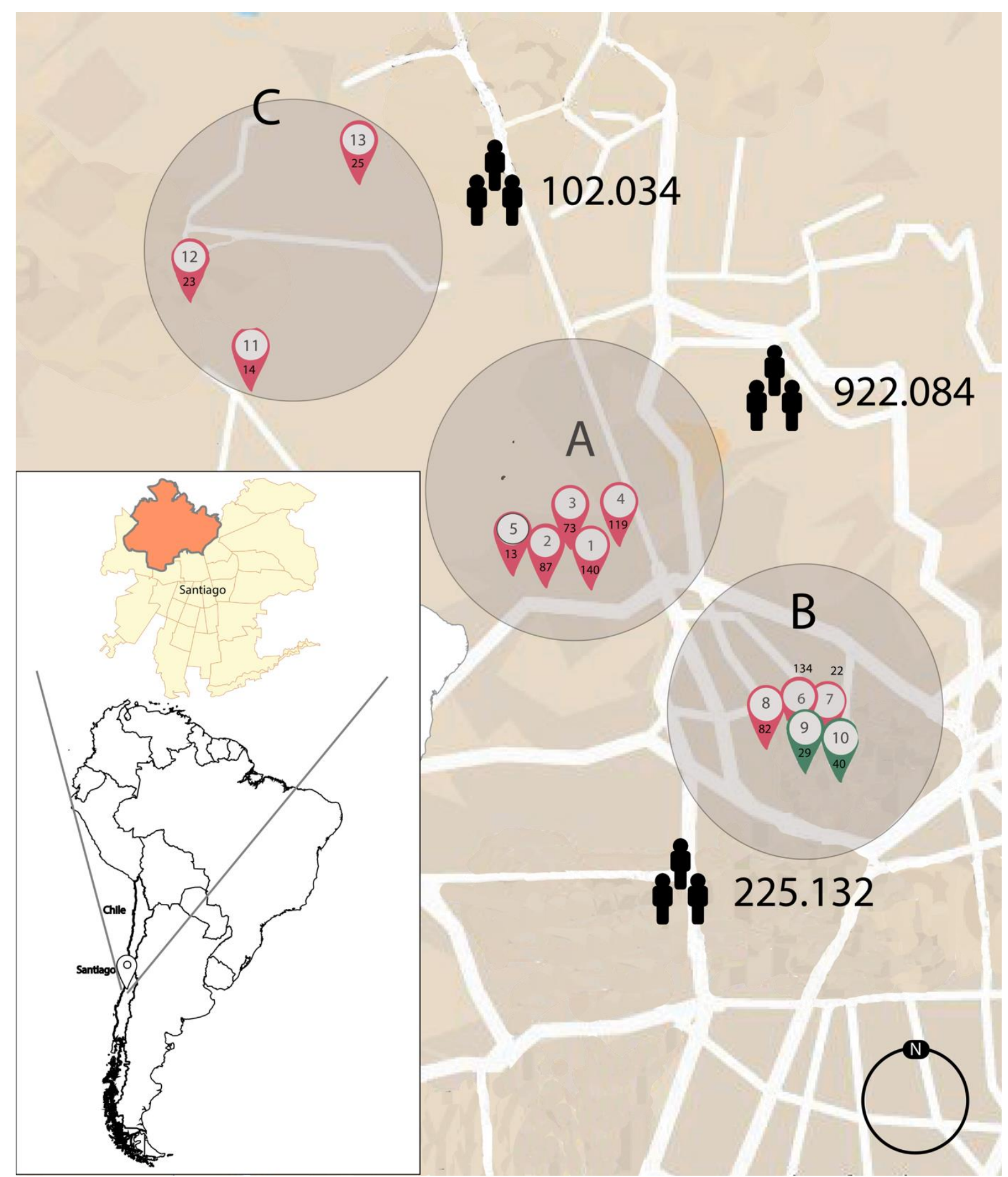

Figure 1: Geographical distribution of the samples analyzed in this study. Distribution of the thirteen-health care center from where the samples were obtained. The figure shows the number of samples by health care center (black number below white circle). Red flag shows health cares center with SARS-CoV-2 positive cases, green flag shows health cares with SARS-CoV-2 negative cases, the human shape indicate population by location (A, B and C). 
medRxiv preprint doi: https://doi.org/10.1101/2021.07.16.21260648; this version posted July 22, 2021. The copyright holder for this preprint (which was not certified by peer review) is the author/funder, who has granted medRxiv a license to display the preprint in perpetuity.

It is made available under a CC-BY-NC 4.0 International license.

228 Table 1.- Co-circulation and co-infection of seasonal respiratory viruses together with

229 SARS-CoV-2 in the Northern area of Santiago, Chile.

230

\begin{tabular}{|c|c|c|c|c|c|c|c|c|}
\hline Location & $\begin{array}{c}\text { Health care } \\
\text { center* }\end{array}$ & SARS-CoV-2 & IAV & IBV & RSV & HRV & $\begin{array}{c}\text { SARS-CoV-2/ } \\
\text { IAV }\end{array}$ & $\begin{array}{c}\text { SARS-CoV- } \\
\text { 2/ HRV }\end{array}$ \\
\hline A & 1 & $82 / 140(58.6 \%)$ & $2 / 140$ & 0 & 0 & $2 / 140$ & 0 & $1 / 140$ \\
\hline A & 2 & $43 / 89(49.4 \%)$ & 0 & 0 & 0 & $1 / 89$ & 0 & 0 \\
\hline A & 3 & $28 / 76(38.4 \%)$ & 0 & 0 & 0 & 0 & 0 & 0 \\
\hline A & 4 & $57 / 117(47.9 \%)$ & $2 / 117$ & 0 & 0 & 0 & $2 / 117$ & 0 \\
\hline A & 5 & $9 / 13(69.2 \%)$ & 0 & 0 & 0 & 0 & 0 & 0 \\
\hline B & 6 & $87 / 134(64.9 \%)$ & $1 / 134$ & 0 & 0 & 0 & 0 & 0 \\
\hline B & 7 & $12 / 22(54.56 \%)$ & 0 & 0 & 0 & 0 & 0 & 0 \\
\hline B & 8 & $48 / 82(58.5 \%)$ & 0 & 0 & 0 & $1 / 82$ & 0 & 0 \\
\hline B & 9 & $0 / 28$ & $1 / 28$ & 0 & 0 & 0 & 0 & 0 \\
\hline B & 10 & $0 / 40$ & $1 / 40$ & 0 & 0 & 0 & 0 & 0 \\
\hline C & 11 & $9 / 14(64.3 \%)$ & 0 & 0 & 0 & 0 & 0 & 0 \\
\hline C & 12 & $7 / 23(30.4 \%)$ & 0 & 0 & 0 & $1 / 23$ & 0 & $1 / 23$ \\
\hline C & 13 & $18 / 25(72 \%)$ & 0 & 0 & 0 & $1 / 40$ & 0 & 0 \\
\hline
\end{tabular}

231

232

* This study includes a total cohort of 800 individuals

233

234

235

236 
medRxiv preprint doi: https://doi.org/10.1101/2021.07.16.21260648; this version posted July 22, 2021. The copyright holder for this preprint (which was not certified by peer review) is the author/funder, who has granted medRxiv a license to display the preprint in perpetuity. It is made available under a CC-BY-NC 4.0 International license .

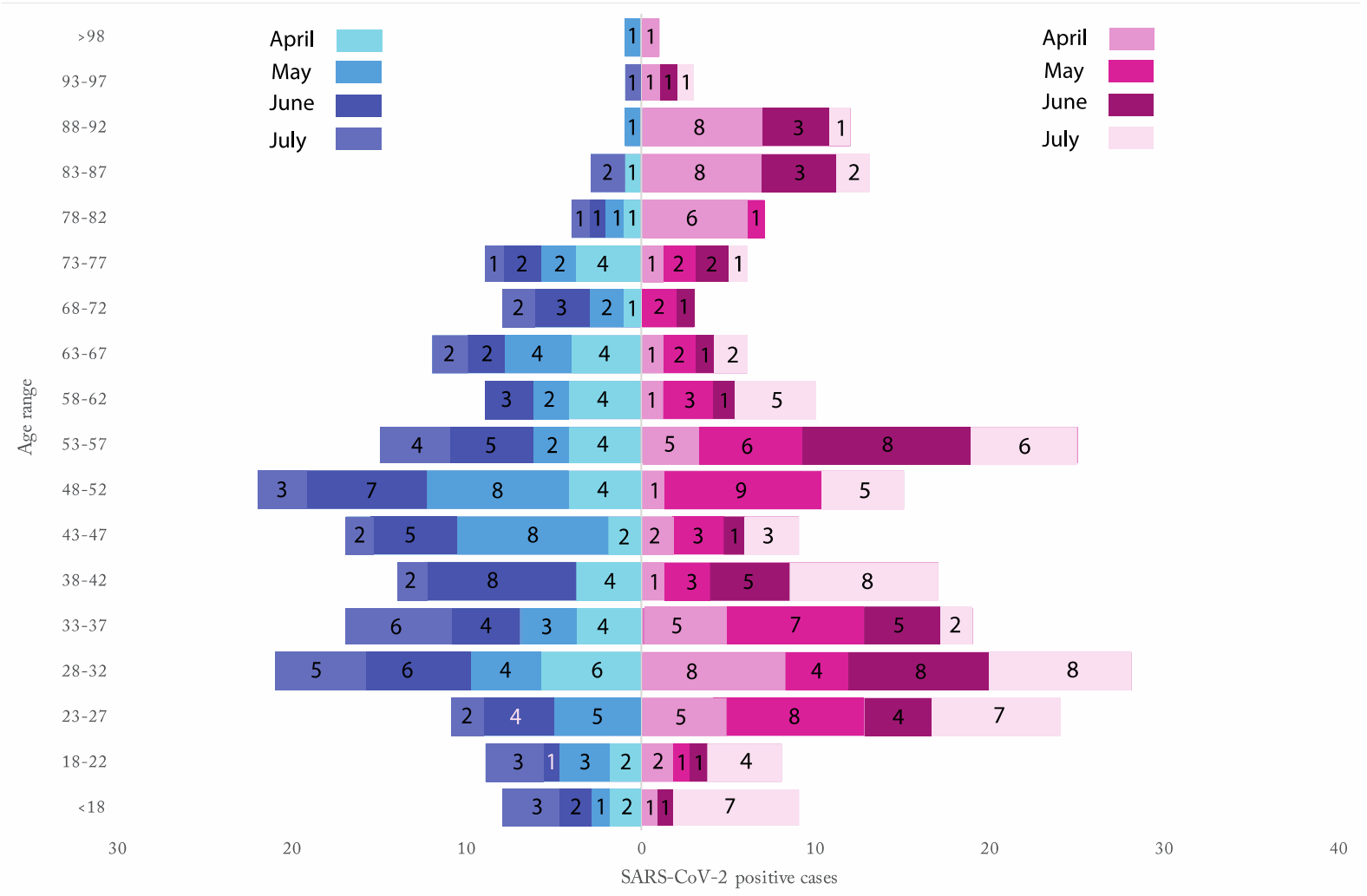

239 Figure 2.- Number distribution of COVID-19 cases according to age group and sex. from 240 April $1^{\text {st }}$ to July $31^{\text {st }}(2020)$ at Santiago of Chile. 400 patients are considered positive for 241 SARS-CoV-2; however, three patients did not provide any information about age and 242 gender. In red is shows female gender and in blue is shows male gender. The numbers in the columns indicate SARS-CoV- 2 positive cases by month. 
medRxiv preprint doi: https://doi.org/10.1101/2021.07.16.21260648; this version posted July 22, 2021. The copyright holder for this preprint (which was not certified by peer review) is the author/funder, who has granted medRxiv a license to display the preprint in perpetuity.

\section{Materials and methods}

\section{Sample selection}

247

248 All samples in this study were obtained with nasopharyngeal swabs come from

249 suspected Chilean population infected with SARS-CoV-2 in the north of Santiago de Chile

250 from different health centers (figure 1). The samples were collected in $2 \mathrm{~mL}$ of RNA-

251 shield media (GenoSUR) and store at room temperature until its analysis for SARS-CoV-

2522 detection.

\section{RNA extraction and Identification of respiratory viruses by RT-qPCR}

254 The RNA extraction was made using the Total RNA Purification Kit (Norgen Biotek CORP);

255 following the manufacturing procedure, the RNA was a store at $-80^{\circ} \mathrm{C}$, which was used 256 to perform RT-qPCR.

257 All samples were analyzed using a specific primer (Supplementary table 1) for SARS-CoV2582 2, IAV, IBV, RSV, and HRV. All sequences have been validated, and their use is a typical 259 procedure to detect respiratory viruses from the World Health Organization (WHO). The 260 viral genome detection was made using LightCycler $^{\circledR}$ Multiplex RNA Virus Master 261 (Roche) following the manufacturing procedure. The amplification and analysis plot was 262 made in a QuantStudio3 Real Time PCR System 96 wells (Thermo Fisher Scientific). The HRV and IBV detection was performed by RT-PCR final point using specific primers, the

264 retrotranscription step was made using SuperScript IV Reverse Transcriptase (Thermo 265 Fisher Scientifics) and PCR was using GoTaq ${ }^{\circledR}$ DNA polymerase (Promega), the genome 266 of HRV was visualized in agarose - Seakem LE Agarose (LONZA) at $2 \%$ applying a voltage 267 of 80 Volts for 30 minutes. 
medRxiv preprint doi: https://doi.org/10.1101/2021.07.16.21260648; this version posted July 22,2021 . The copyright holder for this preprint (which was not certified by peer review) is the author/funder, who has granted medRxiv a license to display the preprint in perpetuity.

Supplementary Table 1.- Primers Sequence for SARS-CoV-2, IAV, IBV, RSV and HRV

277

\begin{tabular}{|l|l|l|}
\hline Virus & Forward & Reverse \\
\hline SARS-CoV-2 & 5' ATGAGCTTAGTCCTGTTG 3' & 5' CTCCCTTTGTTGTGTTGT 3' \\
\hline IAV, & 5' GACCRATCCTGTCACCTCTGA C 3' & $\begin{array}{l}5^{\prime} \text { AGGGCATTYTGGACAAAKCGTCTA } \\
3^{\prime}\end{array}$ \\
\hline IBV, & 5' GGAGCAACCAATGCCAC 3' & 5' GTKTAGGCGGTCTTGACCAG-3' \\
\hline RSV & $\begin{array}{l}\text { 5' AACAGATGTAAGCAGCTCCGTTATC } \\
\text { 3' }\end{array}$ & $\begin{array}{l}\text { 5'- } \\
\text { CGATTTTTATTGGATGCTGTACATTT } \\
\text { 3' }\end{array}$ \\
\hline aHRV & 5'CAAGCACTTCTGTTTCCC 3' & 5'CACGGACACCCAAAGTAGT 3' \\
\hline
\end{tabular}

278

279

280

281

282

283

284

285

286

287 